ISSN 0258-7122 (Print), 2408-8293 (Online)

Bangladesh J. Agril. Res. 42(1): 103-120, March 2017

\title{
MORPHOLOGICAL CHARACTERIZATION OF GEOGRAPHICAL INDICATION LITCHI CROPS AND RELEASED VARIETIES GROWN IN BANGLADESH
}

\author{
M. A. HossAin ${ }^{1}$, M. R. Molla ${ }^{2}$ AND I. AHMED ${ }^{3}$
}

\begin{abstract}
Four Geographical Indication litchi genotypes (GIs) viz., Kadmi Lichu, Mongalbari Lichu, Deshi/Ati/Rajshahi Local (BARI Lichu-1) and Bedana Lichu, and three released varieties viz., BARI Lichu-2, 3 and 4) were characterized morphologically during July 2012 to June 2013 with a view to identifying the degree of morphological and genetic variation of litchi within cultivars, and to establish a permanent database for documentation of litchi. Morphological characterization data were recorded from standing trees of the most concentrated areas of cultivation for GIs and the respective stations from where the variety was released viz., Kadmi from Sonargaon, Narayanganj; Mongalbari from Pakundia, Kishoreganj; Rajshahi Local from Mohanpur village of Shyampur union under Rajshahi district; Bedana from Masimpur, Dinajpur; BARI Lichu-2 and BARI Lichu-3 from RARS, Akbarpur and BARI Lichu-4 from BSPC, Debiganj. Historical background of geographical indication crops of litchi as described by aged people of their most concentrated areas of cultivation indicated that the cultivars were originated naturally in those areas. The cultivars were very location specific. They do not perform well in respect of yield and quality outside their areas of origin indicating their very narrow adaptability range. It was another indication regarding location of origin of the GI crops. On the other hand, the exotic cultivars grown in the country such as BARI Lichu-2, BARI Lichu-3 etc. possess country wide adaptability. Wide variations were observed among the GI crops and released varieties included in this study for plant, leaf, inflorescence, flower and fruit characters. Variation was also recorded in respect of incidence of biotic and abiotic stresses like insect pests, mites, diseases, sunburn, fruit cracking and fruit drop. Each GI/released variety possesses some unique characters, which distinguish it from all other genotypes.
\end{abstract}

Keywords: Litchi, characterization, geographical indication, released varieties.

\section{Introduction}

The litchi (Litchi chinensis) is one of the major fruit crops in Bangladesh. It is a member of the family Sapindaceae. Litchi fruit is famous for its excellent quality, characteristic pleasant flavour and for attractive red colour. Olfert Dapper (1670) wrote that the tree in fruit seems to be decorated with 'purple hearts' which melt like sugar in the mouth and that rightly the litchi should be called 'the queen of

${ }^{1}$ Director, Training \& Communication Wing, Bangladesh Agricultural Research Institute (BARI), Gazipur, ${ }^{2 \& 3}$ Scientific Officer, Plant Genetic Resources Centre, BARI, Gazipur, Bangladesh. 
fruits'. In Bangladesh, it is liked very much as a table fruit and the fruits are in great demand during the season which, however, is rather too short, lasting about one month during May to June. It is also used as an excellent canned fruit. It is admitted that the litchi is a native of the South China (very close to Bangladesh). From China litchi reached Eastern India first via Burma by the end of $17^{\text {th }}$ century and thereafter by the end of $18^{\text {th }}$ century, it was introduced to Bengal (Goto, 1960; Knight, 1980 and Liang, 1981). From Bengal it spread to other parts of India (Pandey and Sharma, 1989). Hence, it can be said that Bangladesh (the then Bengal) is the secondary centre of diversity for this species.

It is grown all over the country sporadically especially in homesteads. In some areas like Dinajpur, Rajshahi, Pabna, Kustia and Chittagong Hill Tracts litchi is grown commercially in small to medium orchards. In some pocket areas of Narayanganj (Sonargaon) and Kishoreganj (Pakundia), it is cultivated in mini orchard form and in homesteads. Area under litchi cultivation in Bangladesh in orchard form is about 1725 hectare and total production in inside and outside orchard is 64995 metric tons (BBS, 2011). Several local and exotic cultivars are grown in the country. The cultivars are mostly location specific. Bangladesh Agricultural Research Institute (BARI) has developed five improved varieties through selection. Some cultivars have been originated in some localities and are being cultivated in those areas from more than several hundred years, which can be termed as geographical indication crops (GIs) for those locality. It is essential to characterize the GIs and released varieties of litchi both in morphological and molecular level for establishment of Intellectual Property Rights (IPR). A project was undertaken by Bangladesh Agricultural Research Council (BARC) to characterize GIs and released varieties of some crops grown in the country with the financial support of Sponsored Public Goods Research - National Agricultural Technology Project (SPGR-NATP) Phase-1. BARI has been assigned with 10 of its mandated crops and litchi is one of them. Four GIs and three released varieties of litchi have been included in this programme for characterization at their morphological level. The present study was, therefore, undertaken to identify the degree of morphological and genetic variation of litchi within cultivars, and to establish a permanent database for documentation of litchi, which will ultimately facilitate establishment of IPR for GI crops of litchi.

\section{Materials and Method}

Selection of trees for GI and released varieties

Seven genotypes of litchi (four GI crops and three released varieties) were characterized morphologically under SPGR-NATP financed project entitled "Characterization of important plant genetic resources" during July 2012 to June 2013. Four GI crops viz., Kadmi Lichu, Mongalbari Lichu, Deshi/Ati/Rajshahi Local (BARI Lichu-1) and Bedana Lichu and three released varieties viz., BARI 
Lichu-2, 3 and 4 was included in this programme. Morphological characterization data were recorded from standing trees. The centre of diversity or most concentrated area of cultivation of the respective GI was identified through discussion with experienced fruit scientists and Department of Agriculture Extension (DAE) Officials at district and upazila level. A team of scientists, involved in this programme, visited Sonargaon upazila of Narayanganj for Kadmi Lichu, Pakundia upazila of Kishoreganj for Mongalbari Lichu, Mohanpur village of Shyampur union under Rajshahi district for Deshi/Ati/Rajshahi Local (BARI Lichu-1), Masimpur village under Dinajpur Sadar upazila for Bedana Lichu, and located the targeted trees of selected GIs. Then three plants were selected in each location for each GI crop for data collection. Each plant was labeled with laminated paper sheet as plant number 1, 2 and 3 for each GI. For released varieties, the team visited Regional Agricultural Research Station, Akbarpur, Moulvibazar for BARI Lichu-2 and BARI Lichu-3; Breeder Seed Production Centre, Debiganj, Panchagarh for BARI Lichu-4 from where the varieties were developed. Discussing with the station heads and working scientific personnel, the original mother tree(s) (OMT) was identified and selected for data collection. In cases where there was only one OMT, daughter mother trees (DMT) were also selected for data collection. Each OMT and DMT was labeled as plant number 1, 2 and 3.

\section{Recording historical background}

Scientists discussed with aged people of the growing areas to find out the historical background of the respective GIs of litchi. The team also located some very old trees (>100 years) as indicated by the nearby people and symptoms on the tree like canopy coverage, trunk circumference, extra-rough trunk surface and galls on trunk etc.

\section{Management practices}

Farmers normally sell their crop as total plantation either in orchard or in homesteads just after harvest of the previous year's fruit. Then entire liability of the plantation goes to the traders. Management practices like pruning, weeding, irrigation, and fertilizer and pesticide application etc. were done by the traders. Chemical fertilizers like urea, TSP, MoP, gypsum etc. were applied at different rates. None of the traders used recommended doses of fertilizers. Pesticides as prescribed by the dealers or experienced traders were used indiscriminately even one or two days before harvesting especially for controlling fruit borer. All traders used to prune the mite infested top shoot during fruit harvesting. In the research stations application of fertilizers and other cultural practices like ploughing, weeding, irrigation, pruning etc. were done as per recommendation of BARI. 


\section{Observation, data collection and record keeping}

The selected trees were visited frequently at different stages of growth, flowering and fruiting. Passport information and morphological data in respect of plant, leaf, flower/inflorescence, fruit and stone characters were recorded following IPGRI Descriptors for Litchi (IPGRI, 2002) at appropriate time. A data collection book was prepared following IPGRI Descriptors prior to initiation of the programme. The photographs of the specific trait considered to be helpful for identification of the variety/cultivar were taken from each genotype at appropriate time of traits to compare the distinctness among them. Data related to distinctness in morphological traits were photographed on each of the seven litchi genotypes.

\section{Results and Discussion}

\section{Historical background}

1. Kadmi Lichu: This cultivar of litchi is commercially cultivated in Sonargaon municipality area, and Mograpara and Bodyerbazar unions of Sonargaon upazila under Narayanganj district. It is also sporadically planted in homesteads of other areas of the upazila. A gentle man namely Amendra Sen planted the first plant of the cultivar in Panamgabtali village under Bodyerbazar union more than 120 years ago. Mr. Saroz Roy established an orchard more than 90 years ago in the same village taking air layerage from this plant. Later on this orchard got reputation in the name of his (Saroz Roy's) son as 'Sadhu's orchard'. The variety spread in other areas of the upazila from this orchard as 'Kadmi Lichu'. At present Hazi Abdul Latif Gazi, a resident of nearby village Haria Chaudhurypara is the owner of this orchard. His father bought this orchard in 1959. Hazi Md. Fazar Ali (more than 90 years old villager) described the history of Kadmi Lichu, which was supported by Hazi Abdul Latif Gazi (65 years).

2. Mongalbari Lichu: Cultivation of this variety was initiated from Mongalbaria village of Pakundia upazila under Kishoreganj district. Commercial cultivation of this variety is still concentrated in this village only. In recent days, some farmers of nearby villages started establishing orchard with this variety seeing its commercial potentiality. The variety was named as per name of the village, where it is commercially grown. There is a close relationship between initiation of cultivation of Mongalbari Lichu and establishment of Mongalbaria Kamil Madrasa. Moulvi Azim Khandaker established the Madrasa in 1802 a.c. and in the same year he planted the first plant of the variety in the Madrasa premises. Later on it has disseminated throughout the village at homestead level. Commercial cultivation was started about 40 years ago. Very large and aged plants were found during visiting the Mongalbaria village. Maulana Md. Toibuzzaman, Principal, Mongalbaria Kamil Madrasa described the history of Mongalbari Lichu. He also 
mentioned that they are maintaining history of both Madrasa and Mongalbari Lichu.

3. Rajshahi Local (Deshi) Lichu/BARI Lichu-1: Rajshahi Local (Deshi) lichu is commercially cultivated in Rajshahi region (Rajshahi, Natore, Chapainawabganj and Pabna districts). Initiation of cultivation of the variety in this region could not be known. Some old plants (more than 100 years) were located in Mohanpur village of Shyampur union under Rajshahi district. Some old men of this area stated that they have been seeing the cultivation of the variety since childhood. Their father or grandfather planted those plants. Most of those plants died due to over age. Md. Shetar Uddin Mondal (about 90 years old) of Mohanpur village described the history of Rajshahi Local (Deshi/Ati) Lichu, which was supported by Md. Aizuddin (about 70 years old). It can be guessed from the statement of the old people that cultivation of Rajshahi Local (Deshi) Lichu has been initiated in this region more than 150 years ago. This cultivar has been released as BARI Lichu-1 in 1996.

4. Bedana Lichu: The general people of the locality confidently stated that cultivation of Bedana Lichu was initiated in Masimpur village under Dinajpur Sadar upazila. A 65 years old villager Md. Azhar Ali claimed that the first plant of the variety was planted by his father in the vicinity of his house more than 100 years ago. About 80 years old villager Md. Asim Uddin told that he has been observing this litchi since his childhood. Some aged plants were found in the village, which were seemed to be over 100 years old. The villagers stated that earlier the variety was called as Kancha Mitha Lichu as it was less sour at green stage. According to their statement, the variety was not much popular before 1980s because of poor bearing. Virtually the variety needs intensive care and nourishment. When litchi attained commercial importance, traders started applying fertilizer and irrigation to litchi orchards. Then it flourished as a quality variety having high yield and its demand increased rapidly, and the price went sky-high within very short time during early 1980s (from Tk.150 to 2000 per 1000 fruits). Based on its colour, seed size and high price someone compared it with pomegranate (which is termed as 'Bedana' in Bangla), and spontaneously the variety was named as 'Bedana Lichu.'

5. BARI Lichu-2: The variety has been selected from exotic germplasm and released in 1996 for cultivation in Bangladesh after a long time evaluation at the Regional Agricultural Research Station, Akbarpur, Moulvibazar. It is a late variety and is suitable for cultivation in eastern and north eastern region of the country.

6. BARI Lichu-3: The variety has been selected from exotic germplasm and released in 1996 for cultivation in Bangladesh after a long time evaluation at the Regional Agricultural Research Station, Akbarpur, Moulvibazar. It is a mid season variety and is suitable for cultivation all over the country. 
7. BARI Lichu-4: The variety has been selected from several locally collected germplasm planted at the Breeder Seed Production Centre (BSPC), Debiganj, Panchagarh and released in 2008 as BARI Lichu-4 for cultivation in the northwestern region of Bangladesh after a long time evaluation. Mr. Md. Abdul Quadir, the then Assistant Agronomist of the centre collected several local germplasm of litchi and planted in the farm during 1960s. Parentage and origin of the variety is unknown. It is assumed that this variety was evolved from chance seedling more than 100 years ago. Md. Asimuddin (100 years old), resident of nearby village Khaturia under Domar upazila of Nilfamari district (former master roll labour of the centre) described the history of BARI Lichu-4. It is a mid season variety and is adapted only in the north-western region of the country. Source of collection, name of collector and actual date of planting of original mother tree (OMT) could not be traced out.

Passport data, plant, leaf, inflorescence/flower, fruit and seed characteristics and incidence of pest and diseases recorded for the geographical indications and released varieties of litchi are presented in tables 1 to 7.

\section{Plant characters}

Results presented in Table 2 revealed that litchi genotypes included in this study varied widely in respect of plant characters like tree vigour, trunk surface, crown shape, growth habit, branching density, branching pattern and young shoot pubescence. Tree vigour was high for GI crops and low or medium in exotic genotypes (BARI Lichu-2, 3). Rajshahi Local/BARI Lichu-1 had the maximum tree height $(12.12 \mathrm{~m})$ and trunk circumference $(278 \mathrm{~cm})$ while BARI Lichu-4 had the minimum tree height $(5.50 \mathrm{~m})$ and BARI Lichu-3 had the minimum trunk circumference $(82 \mathrm{~cm})$. Crown diameter and tree volume were also maximum $(16.56$ $\mathrm{m}$ and $979.25 \mathrm{~m}^{3}$ ) in Rajshahi Local/BARI Lichu-1 and minimum (7.30 m and 99.70 $\mathrm{m}^{3}$ ) in BARI Lichu-3. Variations in quantitative plant characters (tree height, trunk circumference, crown diameter and tree volume) might be due to both genetic behaviour of the genotypes and tree age. Trunk surface was rough in all the genotypes except BARI Lichu-2, which possesses smooth trunk surface. Rajshahi Local/BARI Lichu-1 had distinct crown shape (irregular) as against semi-circular crown shape in other genotypes. Tree growth habit was semi-erect in five genotypes while that in Mongalbari and Bedana was erect. Branching was dense in four genotypes and medium dense in the remaining three genotypes. Branching pattern was irregular in all the genotypes. This might be due to vegetative propagation of the trees through air layering. Only BARI Lichu-2 had glabrous young shoot. That of other genotypes was pubescent. Khurshid et al. (2004) recorded wide variation among litchi cultivars for canopy spread and tree shape, Miao et al. (1998) and Rai et al. (2001) recorded wide variation for tree height. The results are in accordance with the findings of present investigation. 


\begin{tabular}{|c|c|c|c|c|c|c|c|c|c|c|}
\hline & 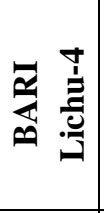 & 离 & 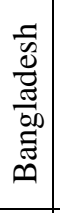 & 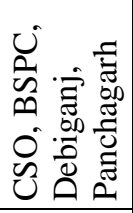 & 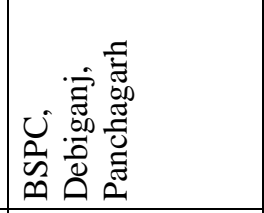 & 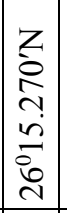 & 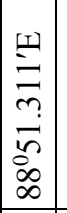 & 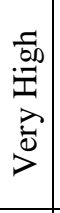 & 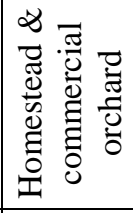 & \\
\hline & 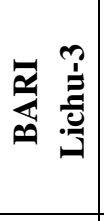 & 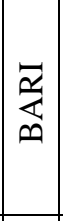 & ' & 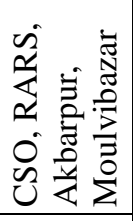 & 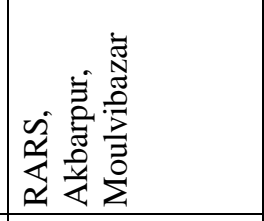 & $\begin{array}{l}z \\
\sim \\
o \\
\infty \\
\sim \\
o \\
o \\
\sim \\
\sim\end{array}$ & 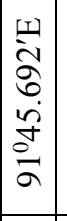 & 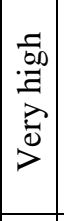 & 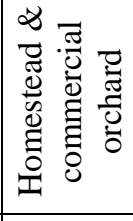 & \\
\hline & 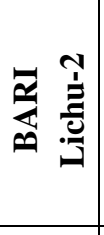 & 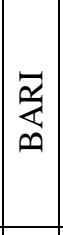 & & 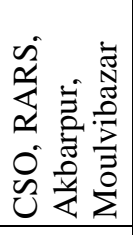 & 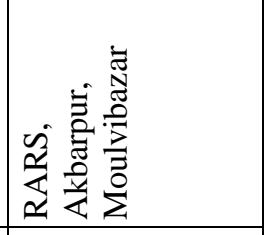 & 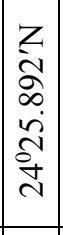 & $\left|\begin{array}{c}1 \\
\bar{a} \\
\hat{\sigma} \\
i \\
\dot{0} \\
0 \\
a\end{array}\right|$ & $\mid \begin{array}{l}\frac{5}{60} \\
.7\end{array}$ & 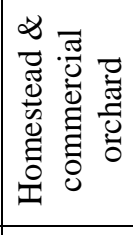 & \\
\hline & 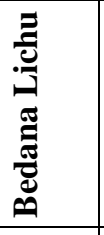 & 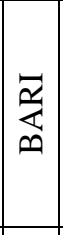 & 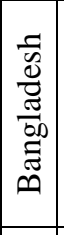 & 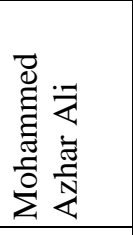 & 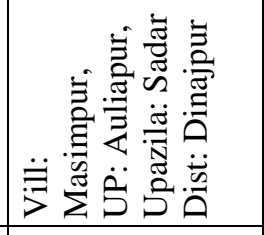 & 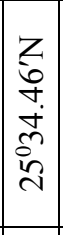 & $\left|\begin{array}{c}1 \\
\\
n \\
n \\
0 \\
0 \\
\infty \\
\infty \\
\infty\end{array}\right|$ & $\mid \begin{array}{c}5 \\
.00 \\
i=7\end{array}$ & 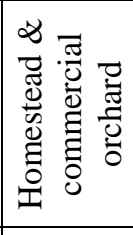 & \\
\hline & 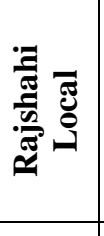 & $\overrightarrow{\underline{z}}$ & 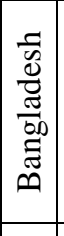 & 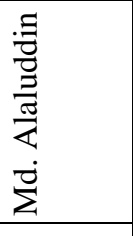 & 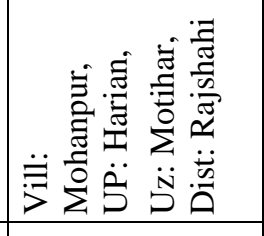 & 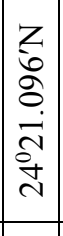 & 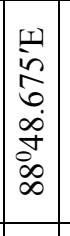 & 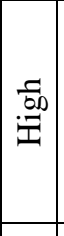 & 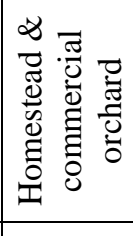 & 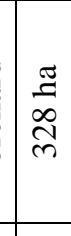 \\
\hline & 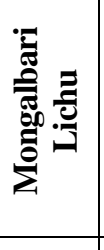 & $\vec{a}$ & 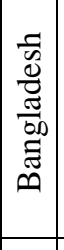 & 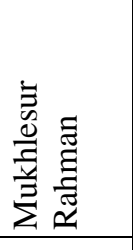 & 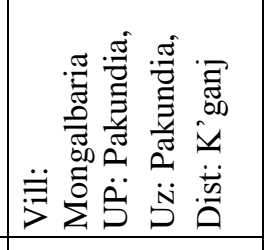 & 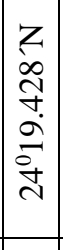 & 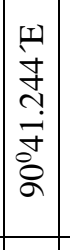 & \begin{tabular}{|l|}
$\frac{5}{60}$ \\
.7
\end{tabular} & 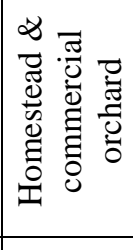 & 孚 \\
\hline & 㞼 & 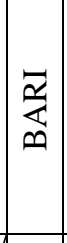 & 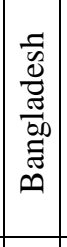 & 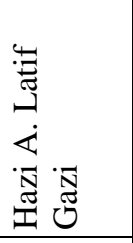 & 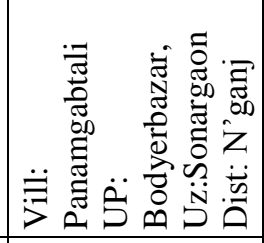 & 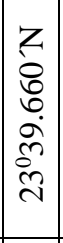 & 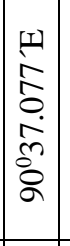 & $\mid \begin{array}{l}5 \\
.000 \\
.7\end{array}$ & 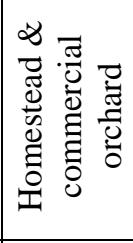 & 孚 \\
\hline & $/$ & 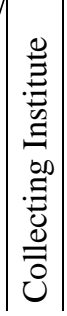 & 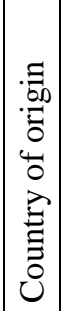 & 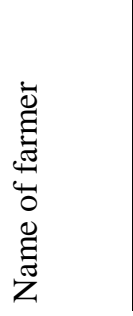 & 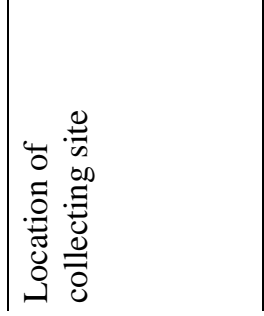 & 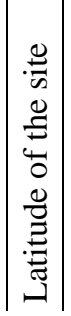 & 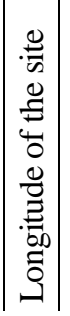 & 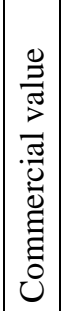 & 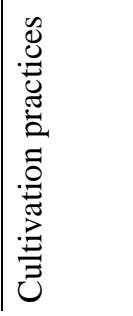 & 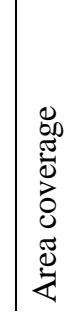 \\
\hline
\end{tabular}




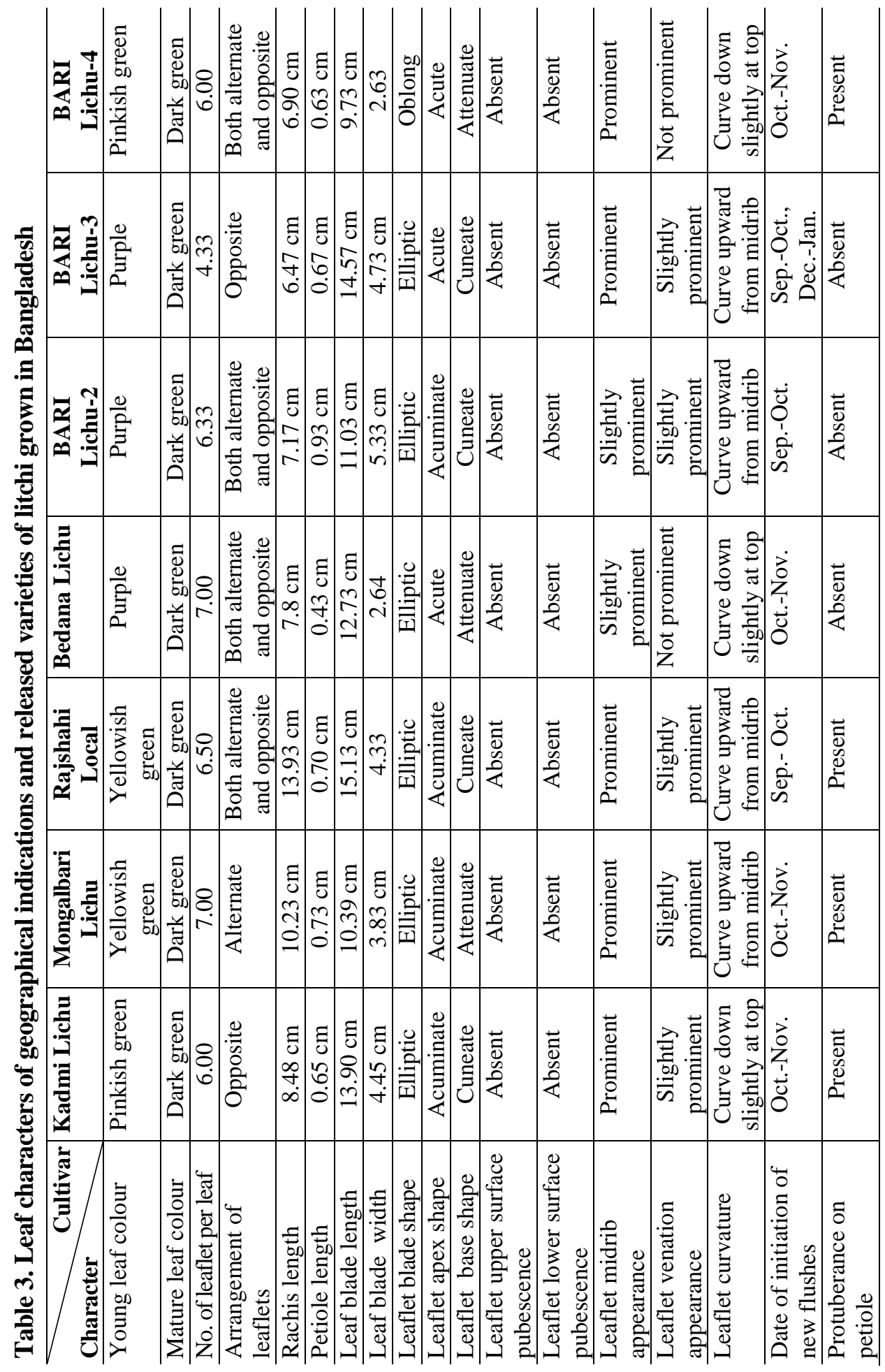




\section{Leaf characters}

Wide variation was observed among the genotypes in respect of all the leaf characters recorded except mature leaf colour, leaflet upper surface pubescence and leaflet lower surface pubescence (Table 3). Young leaf colour was yellowish green in Mongalbari and Rajshahi Local, and purple in other genotypes except Kadmi and BARI Lichu-4 having pinkish green leaf. Singh et al. (1999) noted that litchi cultivars can be distinguished on the basis of young leaf colour. Number of leaflets per leaf ranged from 4.33 in BARI Lichu-3 to 7.00 in Mongalbari and Bedana. Leaflets were arranged in opposite, alternate or both opposite and alternate modes. Rachis length was maximum $(13.93 \mathrm{~cm})$ in Rajshahi Local and minimum $(6.47 \mathrm{~cm})$ in BARI Lichu-3. BARI Lichu-2 had maximum $(0.93 \mathrm{~cm})$ and Bedana had minimum $(0.43 \mathrm{~cm})$ petiole length. Leaf blade length varied from $9.73 \mathrm{~cm}$ in BARI Lichu-4 to $15.13 \mathrm{~cm}$ in Rajshahi Local while leaf blade width varied from $2.63 \mathrm{~cm}$ in BARI Lichu-4 to $5.33 \mathrm{~cm}$ in BARI Lichu-2. BARI Lichu-4 showed distinctness in leaflet blade shape (oblong). Leaf blade shape was elliptic in other genotypes. Leaflet apex shape was acute or acuminate while Leaflet base shape was Cuneate or Attenuate. Protuberance on petiole was present in four genotypes (Kadmi, Mongalbari, Rajshahi Local and BARI Lichu-4) and absent in the remaining three genotypes. Wide variation among litchi cultivars for leaf length, leaf shape, young leaf colour and number of leaflets per leaf was also reported by Khurshid et al. (2004).

\section{Inflorescence and flower characters}

As per opinion of farmers and scientific staff engaged in farm management, first flowering occurred 3-4 years after planting in most of the genotypes (Table 4). Only BARI Lichu-2 flowered earlier (1-2 years). Panicle emerged during mid to late January in four genotypes but in Bedana, BARI Lichu-2 and BARI Lichu-4 it emerged in early February. Panicle emergence continued up to mid or late February, and in some cases (BARI Lichu-2, 3, 4) up to early March. According to Khurshid et al. (2004) environment profoundly influenced cultivar characteristics. So, variation in the time of panicle emergence might be due to varietal character or variation in weather condition among the locations. Mainly three types of flowers were observed in all the genotypes viz. male, functional male and functional female (Pandey and Sharma, 1989). Male or staminate flowers can easily be distinguished by the absence of pistil. The filaments in this type of flower varied in length. The functional female flowers strongly resembled the hermaphrodite flowers with 5-8 contabescent stamens and one bicarpeliate pistil. In functional male flower both pistil and stamens were present but the pistil was non-functional as the lobes of the stigma did not open to permit the entrance of the pollen. These three types of flowers were observed in all the seven genotypes studied. 


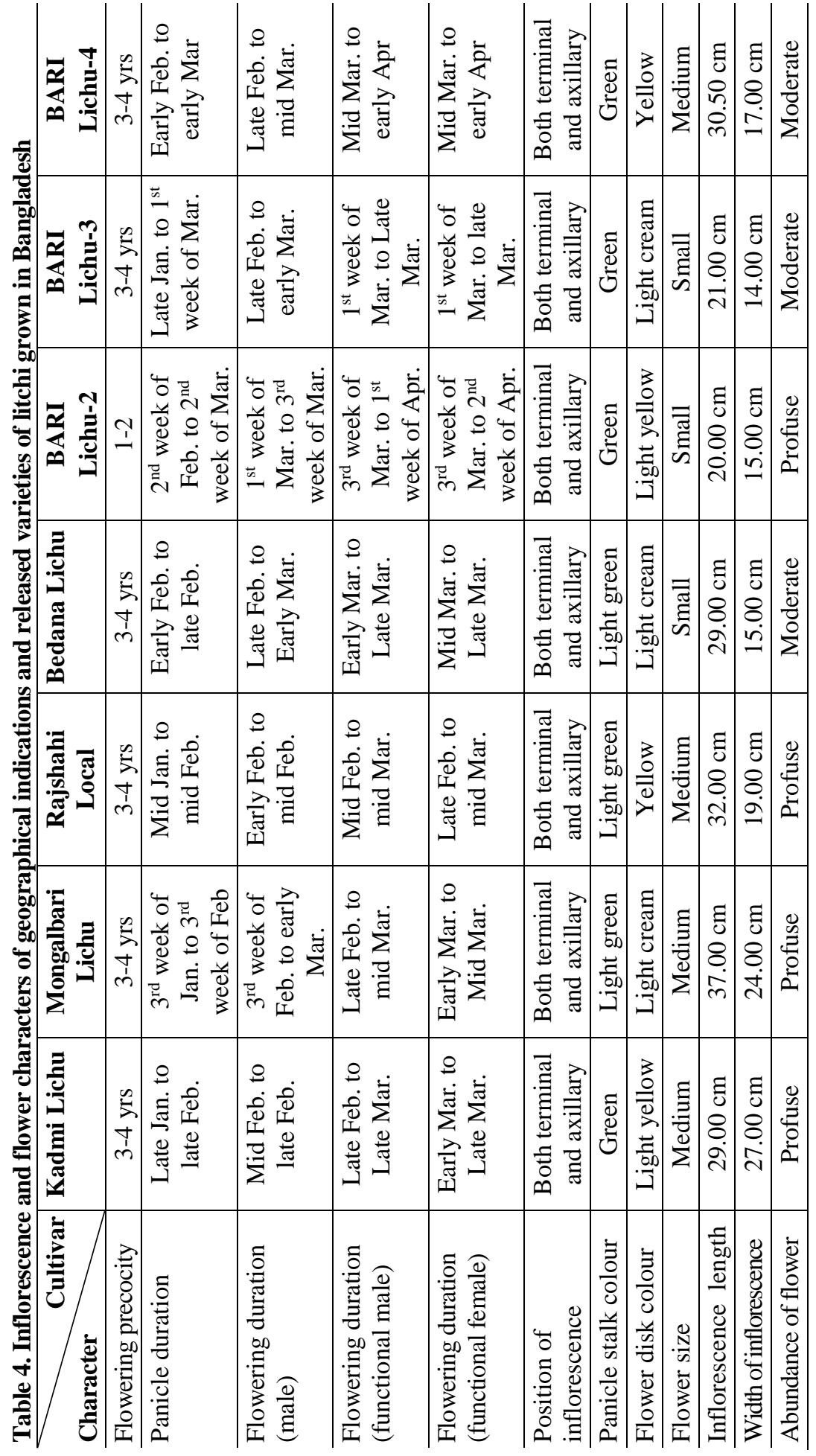


Male flowers opened and dried prior to opening of functional male and female flowers in all the genotypes. Synchronization was observed in anthesis of functional male and functional female flowers resulting successful pollination for fruit setting. Inflorescences were basically terminal in all the genotypes but simultaneously axillary inflorescences were also found. Inflorescence stalk colour was green or light green. Flower disk colour was light yellow in Kadmi and BARI Lichu-2, light cream in Mongalbari, Bedana and BARI Lichu-3. While that of Rajshahi Local and BARI Lichu-4 was yellow. Length of inflorescence ranged from $20.00 \mathrm{~cm}$ in BARI Lichu-2 to $37.00 \mathrm{~cm}$ in Mongalbari. Widest inflorescence $(27.00 \mathrm{~cm})$ was observed in Kadmi and the narrowest $(14.00 \mathrm{~cm})$ in BARI Lichu-3. Profuse flowers were borne by the local cultivars except Bedana while abundance of flowers was moderate in the released varieties except BARI Lichu-2 (profuse).

According to Menzel (1984), and Menzel and Simpson (1992), the flowers are in order of appearance, functionally male, functionally female and functionally male. Menzel (1983) reported that panicles were normally produced terminally in clusters, but in some trees a high percentage of axillary panicles may also be produced. Robbertse et al. (1995) observed that the apical bud of a modular branch produced one inflorescence. One or more of the lateral buds directly below the apical bud were also produced resulting in more than one inflorescence at the tip of a module. All the above results are in conformity with the results of present study.

\section{Fruit characters}

Geographical Indications and released varieties included in this study showed wide variation for almost all the characters recorded in respect of fruits (Table 5). All the genotypes took 4-5 years for fruiting from planting except BARI Lichu-3 which took little longer time (5-6 years). Fruit setting was completed within March in all the genotypes. Kadmi took minimum time (60-65 days) from fruit set to maturity closely preceded by Mongalbari (60-70 days). Maximum time (75 days) was taken by Bedana and BARI Lichu-2. Harvesting duration was also very short for all the genotypes. Narrower variation in fruit set duration and time taken for maturity from fruit set with shorter harvesting duration resulted very short harvesting season for this fruit. As per opinion of the farmers and researchers all the genotypes are regular in bearing. Local cultivars (GIs) except Bedana are heavy bearer while released varieties are medium in bearing intensity. Rajshahi Local had maximum fruits per cluster (17.6) and BARI Lichu-3 had the minimum (3.5).

Fruit shape was oval in Kadmi; oblong in Mongalbari and Rajshahi Local; cordate in Bedana and BARI Lichu-3 and round in BARI Lichu-2 and BARI Lichu-4. Kadmi and BARI Lichu-3 had even fruit shoulder while the shoulder of the remaining genotypes was protruding. Shape of fruit tip was obtuse only in BARI Lichu-3, which distinguished it from other genotypes having round fruit 
tip. Fruit segment was smooth in Kadmi and BARI Lichu-4. That of other genotypes was swelling type. Length of fruit ranged from $3.10 \mathrm{~cm}$ in BARI Lichu-3 to $3.67 \mathrm{~cm}$ in Mongalbari. BARI Lichu-4 produced the widest fruit (3.77 $\mathrm{cm})$ and Rajshahi Local produced the narrowest $(3.10 \mathrm{~cm})$. Mongalbari, Bedana and BARI Lichu-4 were not prone to fruit cracking while in other genotypes fruit cracking was observed at various level. Colour of mature fruit was partially reddish yellow in Kadmi, BARI Lichu-2 and BARI Lichu-3; uniformly rosy red in Mongalbari; partially pinkish red in Rajshahi Local, and uniformly dark red in Bedana and BARI Lichu-4. The genotypes differed from each other in respect of shape and density of tubercles. Fruit suture was prominent in Kadmi, BARI Lichu-2 and BARI Lichu-4 while other genotypes had weak suture. BARI Lichu4 had the maximum fruit $(26.6 \mathrm{~g})$ and aril $(20.6 \mathrm{~g})$ weight, and edible portion $(77.44 \%)$. Fruit weight $(18.0 \mathrm{~g})$, aril weight $(12.30 \mathrm{~g})$ and edible portion (68.33\%) was minimum in BARI Lichu-2. Total soluble solids content in fruit juice varied from $19.78 \%$ in Kadmi to $22.00 \%$ in BARI Lichu-4. Aril flavour was strong in Rajshahi Local and BARI Lichu-4, and intermediate in the other genotypes. Aril quality was very sweet for BARI Lichu-4, sour sweet for Kadmi and sweet for the remaining genotypes. Juicy aril was found in Kadmi, Rajshahi Local and BARI Lichu-2 while the aril of other genotypes was very juicy. Overall taste (eating quality) of Bedana and BARI Lichu-4 was excellent, and that of other genotypes was good to very good.

Pandey and Sharma (1989) reported that litchi fruits are produced in loose clusters of 2 to 20 or even more. The results are in consonance with the findings of the present study. Siddiqui (2002) categorized Rajshahi Local/BARI Lichu-1 as early, BARI Lichu-2 as late and BARI Lichu-3 as mid season variety. He also reported $19.5 \mathrm{~g}, 15.2 \mathrm{~g}$ and $18.4 \mathrm{~g}$ fruit weight, and 18.4 to $20.5 \%, 16.1$ to $20.5 \%$ and $18.9 \%$ total soluble solids content for BARI Lichu-1, BARI Lichu-2 and BARI Lichu-3, respectively which are in line with the results of present study.

\section{Seed characters}

Variation was also noticed for shape, size and colour of seed (Table 6). Mongalbari produced the longest $(2.49 \mathrm{~cm})$ and widest $(1.57 \mathrm{~cm})$ seed while BARI Lichu-3 had the shortest $(1.82 \mathrm{~cm})$ and BARI lichu-2 had the narrowest $(1.30 \mathrm{~cm})$ seed. Individual seed weight was minimum ( $2.30 \mathrm{~g})$ in BARI Lichu-3 closely preceded by BARI Lichu-2 (2.70 g) and BARI Lichu-4 (2.78 g). Maximum seed weight (4.00 g) was recorded in Mongalbari. Oval shaped seed was found only in BARI Lichu-3 while seed shape of other genotypes was oblong. Seed coat colour was dark brown in Kadmi and Mongalbari, dull brown in BARI Lichu-4 and brown in the remaining genotypes. 
116

HossAIN et al.

\begin{tabular}{|c|c|c|c|c|c|c|c|c|c|c|c|c|c|c|c|}
\hline & & & 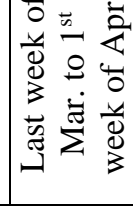 & & & 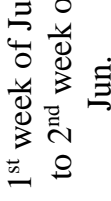 & 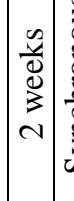 & & & & & 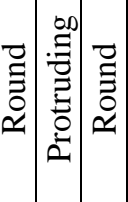 & & & 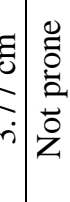 \\
\hline & & $\begin{array}{l}0 \\
i n\end{array}$ & 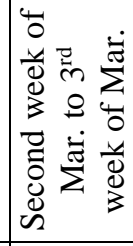 & 离 & & 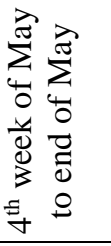 & 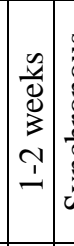 & 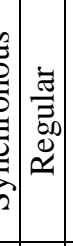 & & "s & & 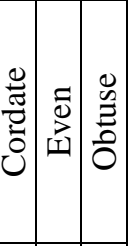 & Bn & & $\stackrel{0}{g}$ \\
\hline & & $\mathfrak{f}$ & 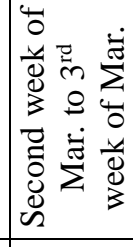 & 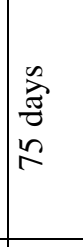 & & 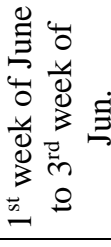 & 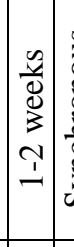 & 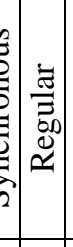 & 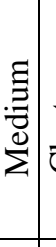 & & & 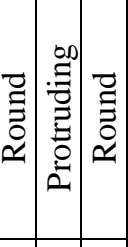 & & & $\begin{array}{c}5 \\
\dot{0} \\
\dot{2}\end{array}$ \\
\hline & ๓ & f & 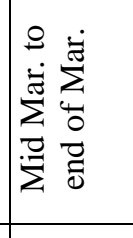 & 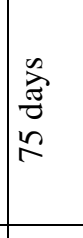 & & 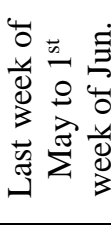 & 党 & & $z$ & & & 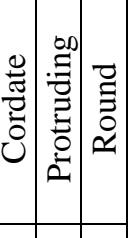 & & & 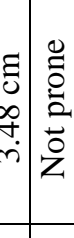 \\
\hline & & $f$ & 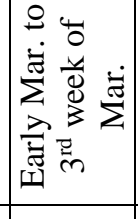 & 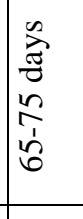 & & 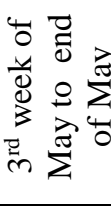 & 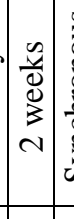 & 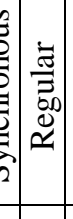 & $\Phi$ & & & 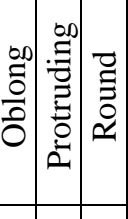 & & & 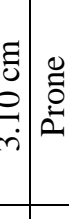 \\
\hline & 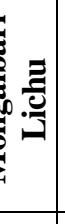 & $f$ & 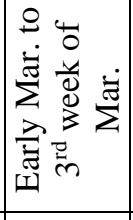 & \begin{tabular}{l}
0 \\
\multirow{2}{*}{} \\
0 \\
0 \\
0 \\
0 \\
0 \\
\end{tabular} & & $\begin{array}{ll} & \\
0 & 0 \\
3 & 0 \\
0 \\
0\end{array}$ & 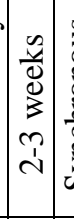 & : & 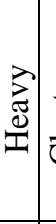 & & & & & & $=$ \\
\hline & 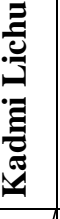 & $\dot{+}$ & 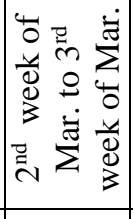 & 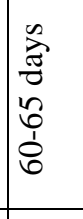 & 勏 & 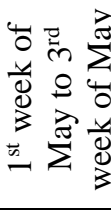 & 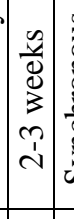 & $\stackrel{2}{2}$ & & & & $\widetilde{8}$ & & & $\begin{array}{c}5 \\
5 \\
5 \\
5\end{array}$ \\
\hline & 18 & 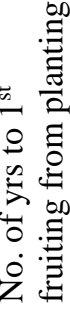 & 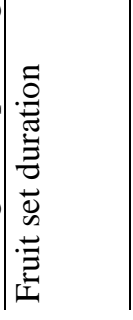 & 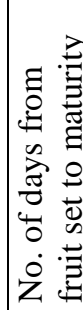 & & 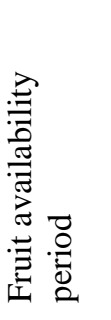 & 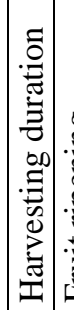 & 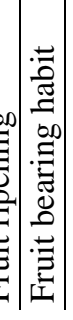 & : & & & 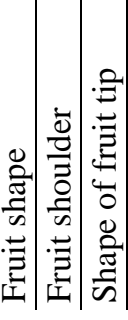 & & & 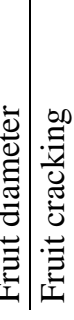 \\
\hline
\end{tabular}




\begin{tabular}{|c|c|c|c|c|c|c|c|c|c|c|c|c|c|c|c|c|c|c|c|}
\hline$\frac{7}{3}$ & 言 & 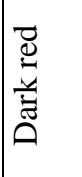 & 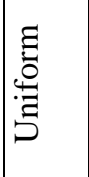 & 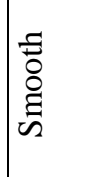 & 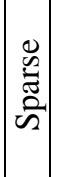 & & 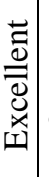 & 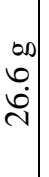 & 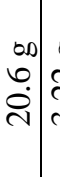 & 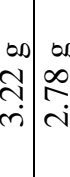 & 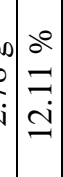 & $\begin{array}{lll}0 & 0 \\
0 & 0 \\
f & 0 \\
0 & 0 \\
0 & 0\end{array}$ & 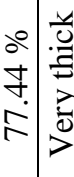 & 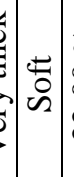 & $\mid \begin{array}{l}0 \\
8 \\
\dot{i} \\
\text { in }\end{array}$ & 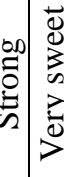 & 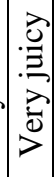 & & 垔 \\
\hline$\frac{2}{2}$ & 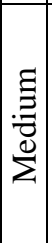 & 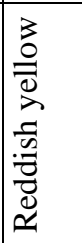 &.$\stackrel{\vec{J}}{\bar{E}}$ & 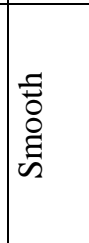 & $\mid \begin{array}{c}0 \\
\tilde{\omega} \\
\tilde{\omega} \\
\tilde{n}\end{array}$ & \begin{tabular}{|l|}
$\frac{1}{0}$ \\
$\frac{0}{3}$
\end{tabular} & $\begin{array}{l}\overrightarrow{0} \\
8 \\
0 \\
0\end{array}$ & $\begin{array}{l}\infty \\
0 \\
\text { in } \\
\end{array}$ & \begin{tabular}{l|l}
$\infty$ & \\
$\infty$ & \\
$\dot{0}$ & \\
- & $\mid$
\end{tabular} & & 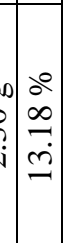 & $\begin{array}{lll}0 & 0 \\
0 & & \\
f & 0 \\
0 & 0 & 0\end{array}$ & 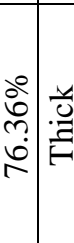 & 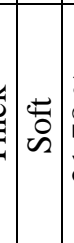 & $\mid \begin{array}{l}0 \\
\infty \\
0 \\
\\
\dot{N}\end{array}$ & 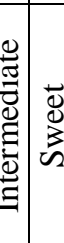 & 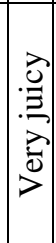 & 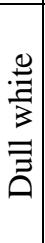 & $\mid$ \\
\hline$\frac{3}{3}$ & 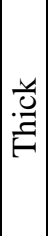 & 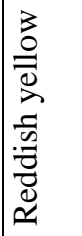 & . & 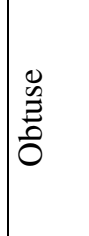 & $\mid \begin{array}{l}\xi \\
: \vec{z} \\
\stackrel{\Xi}{\Sigma} \\
\Sigma\end{array}$ & 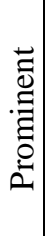 & \begin{tabular}{l|} 
\\
$\vdots$ \\
0 \\
0
\end{tabular} & $\begin{array}{l}\infty \\
0 \\
\infty \\
0\end{array}$ & 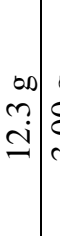 & 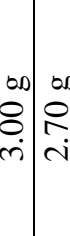 & $\begin{array}{l}0 \\
0 \\
0 \\
0 \\
0 \\
0 \\
0\end{array}$ & $\begin{array}{ll}0 & 0 \\
8 & 0 \\
8 & 0 \\
& 0\end{array}$ & 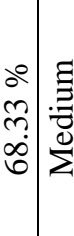 & 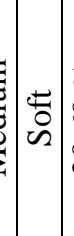 & $\begin{array}{l}0 \\
0 \\
0 \\
0 \\
0 \\
0\end{array}$ & 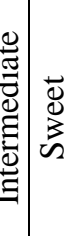 & . & 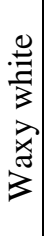 & $\sum_{0}^{\infty}$ \\
\hline 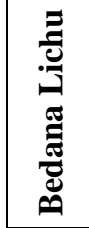 & 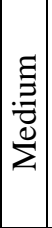 & 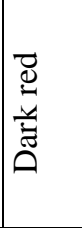 & 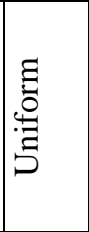 & 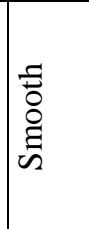 & 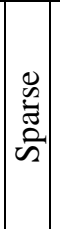 & $\begin{array}{l}\frac{1}{5} \\
3 \\
3\end{array}$ & 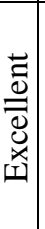 & $\begin{array}{l}\infty \\
0 \\
\dot{d} \\
\end{array}$ & $\begin{array}{ll}\infty & \\
0 \\
0 \\
\infty \\
\infty\end{array} \mid$ & 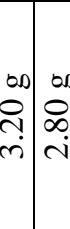 & 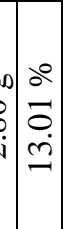 & $\begin{array}{lll}0 & 0 \\
\infty & 0 \\
0 & \vdots \\
= & 0 & 0\end{array}$ & 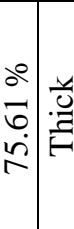 & 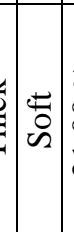 & 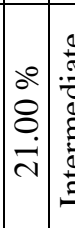 & 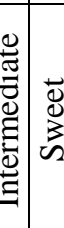 & 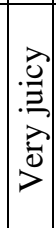 & 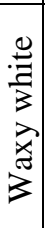 & 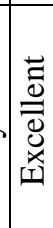 \\
\hline 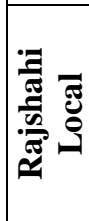 & $\left|\begin{array}{l}\Xi \\
: \vec{\Xi} \\
\frac{\vec{\Xi}}{\Sigma} \\
\Sigma\end{array}\right|$ & 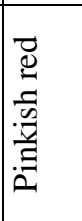 & 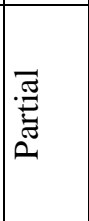 & 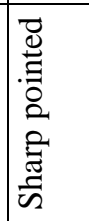 & 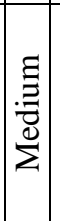 & $\begin{array}{l}\frac{y}{5} \\
3 \\
3\end{array}$ & $\begin{array}{l}- \\
\vdots \\
0 \\
0\end{array}$ & $\begin{array}{l}\infty \\
0 \\
\dot{0} \\
\end{array}$ & $\begin{array}{ll}\infty & 0 \\
0 \\
\dot{ \pm}\end{array}$ & & 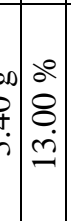 & 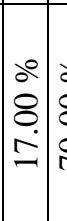 & 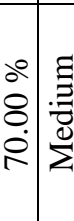 & 思 & 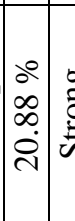 & 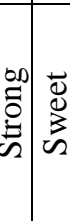 & 忥 & 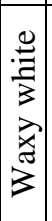 & 3 \\
\hline 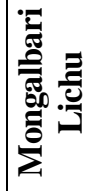 & E & 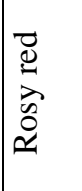 & 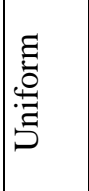 & 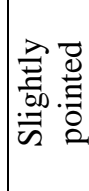 & 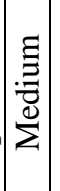 & \begin{tabular}{|l}
$\frac{y}{5}$ \\
3 \\
3
\end{tabular} & $\begin{array}{l}- \\
\vdots \\
0 \\
0\end{array}$ & $\begin{array}{l}\infty \\
0 \\
\dot{i} \\
\text { | }\end{array}$ & 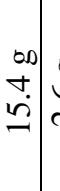 & & 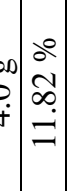 & 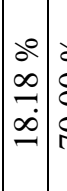 & 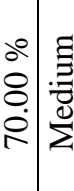 & 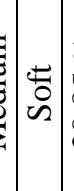 & 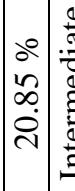 & 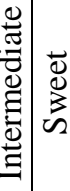 & 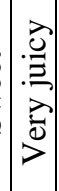 & 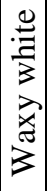 & 8 \\
\hline 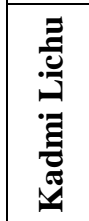 & $\bar{z}$ & 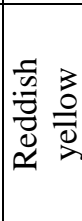 & : & 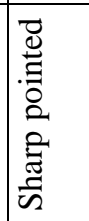 & $\mid \begin{array}{l}0 \\
\ddot{D} \\
\bar{D} \\
0\end{array}$ & 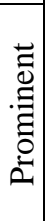 & $\begin{array}{l}- \\
8 \\
0 \\
0 \\
\end{array}$ & 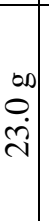 & $\begin{array}{l}0 \\
0 \\
\stackrel{0}{0} \\
-\end{array}$ & 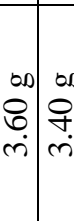 & 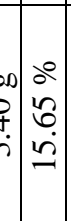 & $\begin{array}{ll}0 & 0 \\
\infty & 0 \\
0 & 0 \\
\dot{ \pm} & 0\end{array}$ & 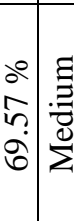 & 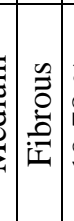 & $\begin{array}{ll}0 & 0 \\
\infty & 0 \\
2 & 0 \\
2 & 0 \\
2 & 0\end{array}$ & 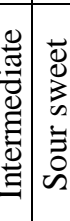 & 离 & 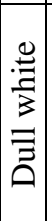 & ס \\
\hline 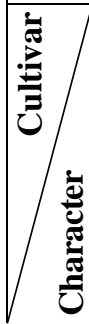 & 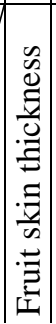 & 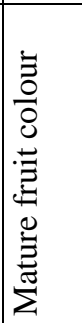 & 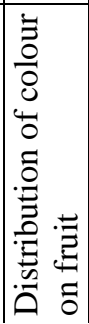 & 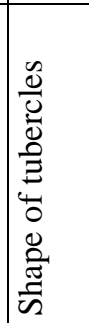 & 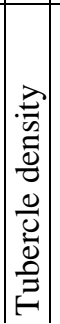 & $\left|\begin{array}{l}\vec{w} \\
\overrightarrow{0} \\
0 \\
0 \\
\tilde{v}\end{array}\right|$ & . & 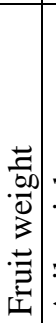 & 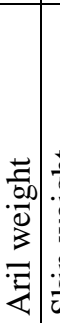 & 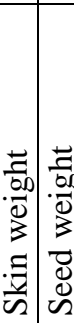 & 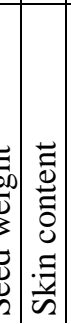 & 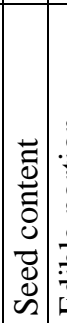 & 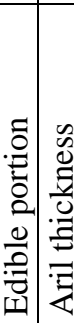 & 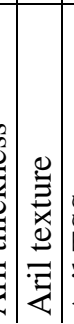 & 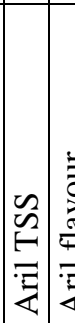 & 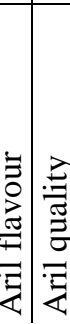 & 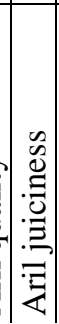 & 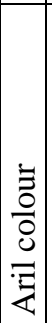 & \\
\hline
\end{tabular}


118

HossAIN et al.

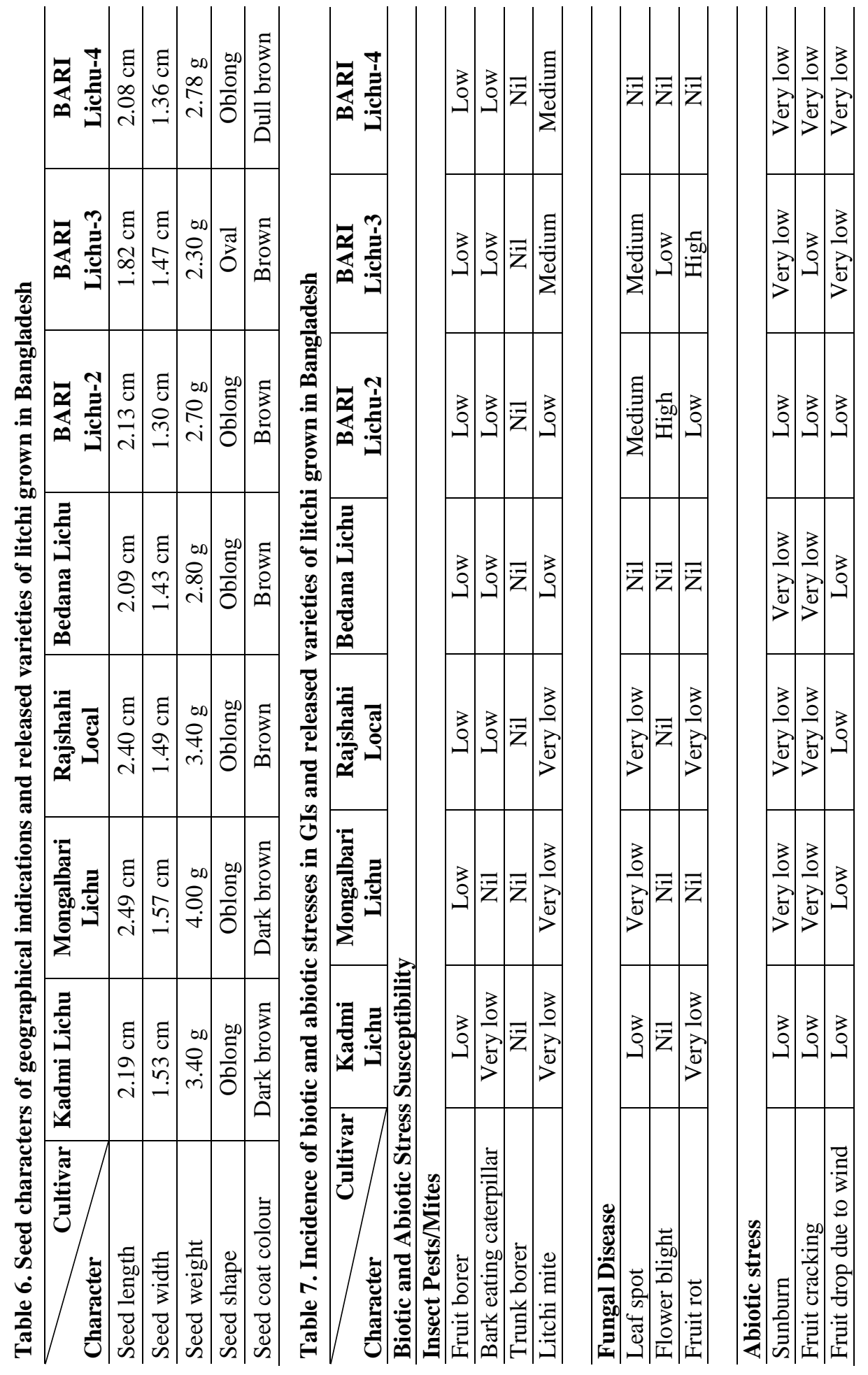




\section{Incidence of biotic and abiotic stresses}

Incidence of biotic and abiotic stresses was recorded at varying level among the genotypes (Table 7). All the GIs and BARI Lichu-4 showed highly resistant to resistant reaction against all the stresses recorded under natural epiphytotic condition. But medium to high incidence of leaf spot, flower blight and fruit rot was recorded in BARI Lichu-2 and BARI Lichu-3.

\section{Conclusion}

Historical background of geographical indications of litchi as described by aged people of their most concentrated areas of cultivation indicated that the cultivars have been originated naturally in those areas. The cultivars possess high commercial value and are being cultivated widely around their areas of origin. Every GI possesses some special characters, which it might gain from its habitat. Each genotype had some unique characters, which distinguished it from all other genotypes. Considering all characteristics, BARI Lichu-4 can be ranked as the best among the genotypes studied. Some of the GIs viz. Bedana and Rajshahi Local are located along the periphery of the country. Both Bangladesh and India can claim them as their own property. It is essential to give proper attention to establish legal rights on these invaluable wealth of the country. For identification of the degree of morphological and genetic variation of litchi within cultivars and establishment of Intellectual Property Rights (IPR), characterization at molecular level is essential. Immediate action should be undertaken to perform molecular characterization of the geographical indications and released varieties of litchi with ultimate goal to provide necessary information for establishment of IPR on the same.

\section{References}

BBS. 2011. Yearbook of Agricultural Statistics of Bangladesh 2010. Bangladesh Bureau of Statistics, Statistics Division, Ministry of Planning, Government of the People's Republic of Bangladesh, Dhaka. P. 139.

Goto, Y.B. 1960. Lychee and its processing. Pacific Region Food Conference 1:15-23.

IPGRI. 2002. Descriptors for Litchi (Litchi chinensis). International Plant Genetic Resources Institute, Rome, Italy. 68p.

Khurshid, S., I Ahmed and M.A. Anjum. 2004. Genetic diversity in morphological characteristics of litchi. Int. J. Agri. Biol. 6(6): 1062-65.

Knight, R.J. 1980. Origin and world importance of tropical and sub-tropical fruit crops. In: Tropical and Sub-tropical Fruits: Composition, Properties and Uses. S. Nagy and P.E. Shaw (Ed.), AVI Publishing Westport, Connecticut. 1-120 pp.

Liang, J. 1981. The litchi, origin, utilization and development of its culture. J. Agri. Trinidad Bot. Applied. 28: 259-70 
Menzel, C.M. 1983. The control of floral initiation in lychee: A review. Sci. Hort. 21:201-215.

Menzel, C.M. 1984. The pattern and control of reproductive development in lychee: A review. Sci. Hort. 22:333-345.

Menzel, C.M. and D.R. Simpson. 1992. Flowering and fruit set in lychee (Litchi chinensis Sonn.) in subtropical Queensland. Austal. J. Expt. Agr. 32: 105-111

Miao, P.S., J. Han, Y.Q. Huang, D. Lin and F.N. Wang. 1998. Introduction of four new litchi selections. China Fruits. 2: 53.

Olfert Dapper. 1670. Quoted from 'The Litchi' written by Pandey, R.M and H.C. Sharma (1989) and published by Indian Council of Agricultural Research, New Delhi. P. 1

Pandey, R.M and H.C. Sharma. 1989. The Litchi. Indian Council of Agricultural Research, New Delhi. 80p.

Rai, M., M.N. Reddy and V.S.R.K. Prasad. 2001. Variation pattern in litchi under India condition. Indian J. Hort. 58: 218-23

Robbertse, H., J. Fivaz and C. Menzel. 1995. A reevaluation of tree model, inflorescence morphology and sex ratio in lychee (Litchi Chinensis Sonn.). J. Amer. Soc. Hort. Sci. 120(6): 914-20.

Siddiqui, S.B.M.A.B. 2002. Lychee Production in Bangladesh. In : Minas K.P and J.D. Frank (Ed.) Lychee Production in the Asia Pacific Region. Published by FAO Regional Office for Asia Pacific, Bangkok, Thailand. Pp. 28-40.

Singh, K., B.M. Chowdhury, R. Shankar and B.P. Jain. 1999. Studies on the physiological changes in litchi fruits during growth and development under Ranchi condition. Prag. Hort., 31: 151-55. 